\title{
マウンド上の洗掘防止マットの設計手法に 関する実験的検討
}

\author{
喜寻 司 1 - 大野 俊夫 2 - 星野 太 $^{3} \cdot$ 鈴木 高二朗 4 \\ 1正会員 港湾空港技術研究所（下239-0826 神奈川県横須賀市長瀬3丁目1-1） \\ E-mail:kita-t@pari.go.jp \\ 2フェロー会員日本海上工事株式会社＼cjkstart技術部（干112-0004 東京都文京区後楽1丁目7-27） \\ E-mail:ohno-t@kaijyokouji.co.jp \\ 3正会員日本海上工事株式会社＼cjkstart技術部（广112-0004 東京都文京区後楽1丁目7-27） \\ E-mail:hoshino@kaijyokouji.co.jp \\ ${ }^{4}$ 正会員 港湾空港技術研究所 （广239-0826 神奈川県横須賀市長瀬3丁目1-1）
}

E-mail:suzuki_k@pari.go.jp

\begin{abstract}
津波の防波堤越流による水平波力増大やマウンドの洗掘による防波堤の滑動・転倒を防ぐ対策として, 腹 付工上への洗掘防止マットの敷設が提案されているが，マットの検討は十分に行われていない，そこで， 本検討では防波堤背後の腹付工に設置された洗掘防止マットに越流を作用させる水理模型実験を行い, 腹 付工上の洗掘防止マットの設計手法やマットによるマウンドの安定性についての検討を行った。実験では, マットに生じたひずみを測定し，マットに働く引張応力を推定した。その結果をマットに衝突する越流水 の運動量で整理することで, 種々の越流に対する最大引張応力を推定する実験式を示した. また, 試設計 を行い, 必要強度の算定方法を提案した。 さらに, マットとその上に設置した被覆ブロックの付着で, ブ ロックの安定性が増大寸ることを確認した。
\end{abstract}

Key Words : tsunami, overflow, breakwater, scouring protection mat

\section{1. はじめに}

2011年の東日本大震災による津波で，多くの防波堤が 滑動・転倒した．その対策として，水平波力に耐えるた めの腹付工と津波越流による腹付工の洗掘を抑制するた めの洗掘防止工（洗掘防止マット）, 被覆工が提案され ている1).

腹付工の水平波力への効果や被覆工の洗掘を抑制する 効果に関しての研究 (例えば有川ら $\left.{ }^{2)}\right)$ や, 被覆ブロッ クの必要質量の算定手法についての研究（例えば三井ら 3)）は行われているが, 洗掘防止工の必要強度について の検討は行われていない，また，有川ら ${ }^{4} は ，$ 水理模型 実験において, 越流による流速の影響で洗掘防止マット を想定して上部マウンドのみに設置したアスファルトマ ットが破損し，そこから洗掘が発生したことを報告して いる. 現地においても洗掘防止マットが破壊される可能 性が想定されるが，現在，港湾の施設の技術上の基準・ 同解説では，マットの強度は法先の洗掘防止マットに関 するもののみで，腹付工上部に設置するマットについて の十分な検討は行われていない.

そこで本検討では，腹付工上部に設置した洗掘防止マ
ットに越流を定常的に作用させる水理模型実験を行った. 越流作用中にマット表面に生じたひずみを計測し，その 結果から引張力を推定し, マットの必要強度の算定手法 を検討することを目的とした。

\section{2. 研究内容}

\section{(1) 解析におけるマットの取り扱い}

洗掘防止マットには，一般に，アスファルトを主とし た合材に芯材をいれ補強したものが用いられる. 本実験 においても，現地のたわみ性を再現するため，改質アス ファルトに芯材を入れたものを使用した. そのため, ア スファルトマットの変形は本来, 断面で不均一となる. また, アスファルトマットは, マウンド内を浸透して作 用する流れ，揚圧力によって浮き上がらないよう，有孔 に加工してあり (図-1 平面図参照)，その影響で平面 的にも不均一な変形を生じるが，本検討では，マットを 一様断面とみなして検討を行った.

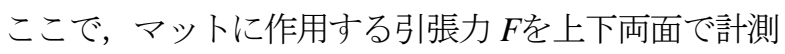
されたひずみから算定する方法について示す. マットに 生じる力は一般に, 軸方向の力 $F$ と曲げモーメント $M$ と 


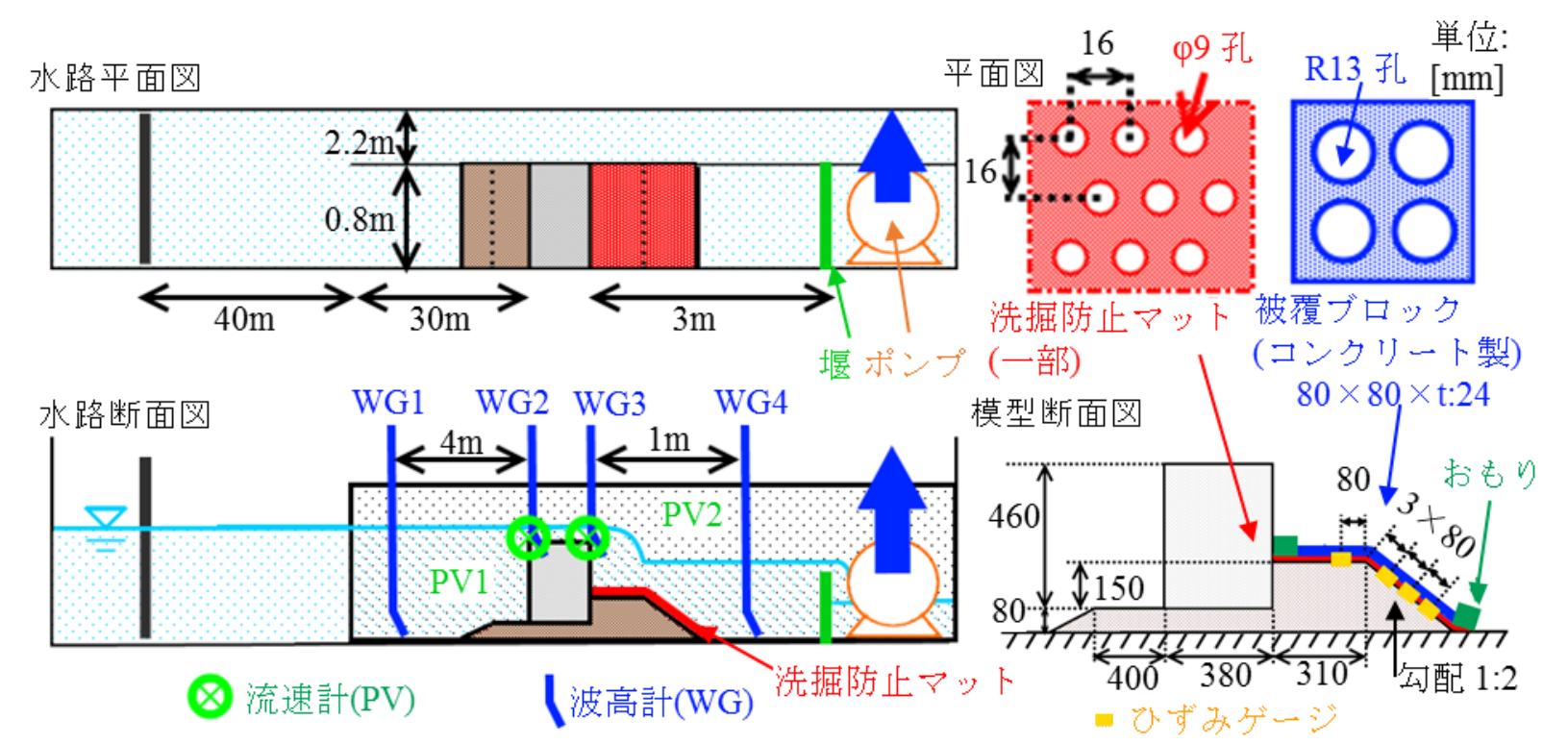

図-1 実験水路・模型図（左 : 水路平面図・水路断面図，右 : 平面図・模型断面図）

なる（図-2 参照）。端部，石との境界部ではせん断力 が作用するものの，本検討では考慮しない．

任意の断面ABについて，Fにより断面積 $A$ 当りに作用 する力, つまり引張応力 $\sigma_{F}$ と， モーメント $M$ によって 発生する最大応力 $\sigma_{M}$ について考える (図-2 参照) 。ひ ずみが微小で応力と線形関係にある弾性範囲では, マッ 卜上面，下面に生じるひずみ $\varepsilon A ， \varepsilon B$ は， $\varepsilon F ， \varepsilon M$ を用い て図-3のような関係となる．よって $F$ は式(1)のように算 定できる.

$$
F=\sigma_{F} A=E \varepsilon_{F} A=E \frac{\left(\varepsilon_{A}+\varepsilon_{B}\right)}{2} A
$$

ここで， $E$ :ひずみに対する応力の比例係数，つまり， ヤング率である，なお，本実験においてマットのひずみ 一応力関係が線形であったことは後述する物性試験で確 認した.

\section{(2) 水理模型実験}

\section{a) 実験条件}

水理模型実験は，港湾空港技術研究所所有の $105 \mathrm{~m}$ 造 波水路で実施し，縮尺1/25の防波堤模型を設置した（図 -1 参照）。基礎マウンド，腹付工には縮尺を考慮し5号 砕石を使用した．洗掘防止マット模型は，厚さが約 2.5 $\mathrm{mm}$ 程度であり, 揚圧力低減のため, 開口率 $20 \%$ の有孔 とした. マットは，腹付工全体に敷設した．その際，上 からおもりをのせて荷重をかけ，また，ドライヤーで温 めることで，現地での腹付工の捨石や被覆ブロックへの アスファルトマットの付着を模擬した（図-4参照）。 また，越流によりマットが浮き上がらないよう，その前 後端には根固工としておもりを設置し固定した.

マットには，上下両面にひずみゲージを取り付け，動 ひずみアンプに接続し，越流中にマット表面に生じる

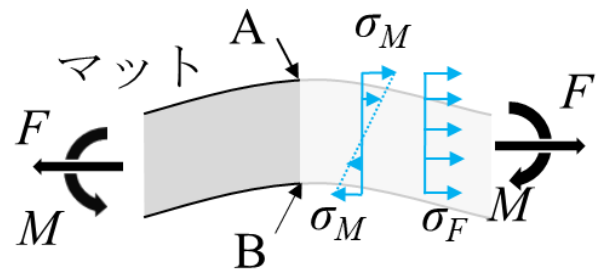

図-2 マットの断面 $\mathrm{AB}$ に作用する応力 $\sigma$ のイメージ

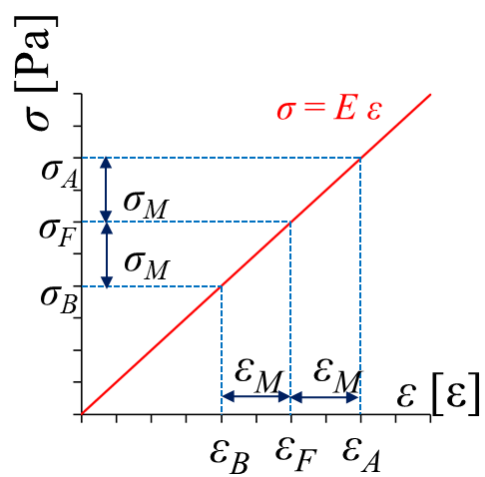

図-3 応力 $\sigma-$ ひずみ $\varepsilon$ 関係

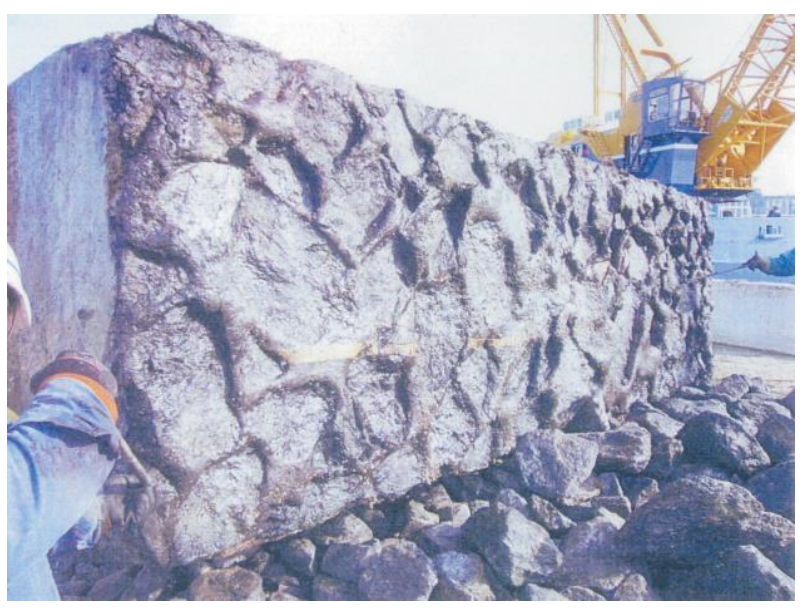

図-4＼cjkstart現地のアスファルトマットがケーソン下面に付着してい る様子 
表-1 実験ケースごとのひずみ $\varepsilon F$

\begin{tabular}{|c|c|c|c|c|c|c|c|c|c|c|c|c|}
\hline \multicolumn{7}{|c|}{ 被覆ブロックなし } & \multicolumn{5}{|c|}{ 被覆ブロックあり } & \multirow{2}{*}{$\begin{array}{c}\text { 必要質量 } \\
m[\mathrm{~g}] \\
\end{array}$} \\
\hline$h_{f}[\mathrm{~cm}]$ & $h_{r}[\mathrm{~cm}]$ & case & St1 $[\mu \varepsilon]$ & St2 $[\mu \varepsilon]$ & St3 $[\mu \varepsilon]$ & $\mathrm{St} 4[\mu \varepsilon]$ & case & St1 $[\mu \varepsilon]$ & $\mathrm{St} 2[\mu \varepsilon]$ & St3 $[\mu \varepsilon]$ & $\mathrm{St} 4[\mu \varepsilon]$ & \\
\hline 61 & 53 & 1 & -13.4 & -12 & -10.3 & -13.2 & $16^{* *}$ & -18.2 & -14.8 & -12 & -6 & \\
\hline 61 & 48 & 2 & -1.6 & -1.5 & -8.1 & -3.1 & 17 & 0.3 & 1.1 & -3 & 1.3 & \\
\hline 61 & 44 & 3 & 3 & -22.2 & -7.5 & -16.9 & 18 & 1.3 & -1.4 & -6.6 & 1.7 & \\
\hline 61 & 38 & 4 & 6.6 & -20.1 & -1.4 & 3.6 & 19 & -0.1 & -2.2 & -8.4 & 2.4 & \\
\hline 61 & 33 & 5 & -11.3 & -16.6 & -3.1 & -0.7 & 20 & 5.6 & -3.8 & -10.3 & -0.1 & 22 \\
\hline 59 & 28 & 6 & 47.9 & 7.9 & 9.5 & 8.9 & $21 *$ & 15.1 & -1.4 & -8 & 2.4 & 147 \\
\hline 64 & 51 & 7 & -16.5 & -15.4 & -17.1 & -19.5 & 22 & $\mid-6.1$ & -4 & -6.6 & -0.2 & \\
\hline 64 & 46 & 8 & -40.2 & 2.7 & 24.5 & -3.4 & 23 & $\mid-7$ & -4.4 & -12 & -0.2 & 19 \\
\hline 64 & 41 & 9 & 2.9 & 8.1 & 38.6 & 49.8 & 24 & 0.2 & 2.5 & -5.1 & 0.9 & 47 \\
\hline 64 & 37 & 10 & 19.2 & 17.4 & 57.6 & 12.9 & 25 & 16.5 & 54.8 & -27.3 & -1.8 & 68 \\
\hline 64 & 31 & 11 & 30.9 & 14.9 & 48.5 & 9.7 & 26 & -2.4 & 18.7 & -47.8 & -8.3 & 300 \\
\hline 69 & 50 & 12 & 6.5 & 75.3 & 41.1 & -19.1 & 27 & -11.6 & -0.3 & -13 & 0.9 & 76 \\
\hline 69 & 45 & 13 & 24.8 & 105.3 & 53.4 & -13.6 & $28 * *$ & -11.8 & -15.9 & -10.3 & 4.5 & 260 \\
\hline 69 & 39 & 14 & 54.9 & 153.1 & 110.3 & -12.8 & 29 & -10.2 & 3.4 & -12.6 & -0.9 & 563 \\
\hline 69 & 35 & 15 & 83.1 & 200.8 & 172 & 58.1 & $30^{* *}$ & -5.9 & 22.9 & -4.3 & -18.7 & 1102 \\
\hline
\end{tabular}

$h_{f}$ 前面水位 $h_{r}$ : 背面水位

St1:マウンド水平部のひずみ計

St2:〜St4:マウンド法肩より80,160,240mmのひずみ計

ひずみの測定を行った。なお，ひずみゲージは図-1の模 型断面図に示した位置のマットの上下両面に設置した. また，堤体前後端に容量式波高計，プロペラ式流速計を 配置し，越流の状況の計測も併せて行った.

実験は，模型が水没した状態で開始した．実験開始後， ポンプを起動させ，模型背後に設けられた貯留槽内を排 水しその水位を下げることで循環流による越流を各ケー ス4分間発生させた（図-5参照）。

実験ケースは，図-1の水路断面図に示す波高計WG1 で測定した前面水位 $h_{f}$ とWG4で測定された背面水位 $h_{r}$ の 組み合わせとした（表-1参照）。ここで， $h_{r}$ は，貯留槽 と模型背後を仕切る堰の高さによって調整した．実験に ついてはケース番号順に行った. case12〜 case14で腹付工 法面の砕石が一部崩れたが (図一参照)，以降のケー スが，背後水深 $h r$ はより小さくなり，被災も大きくなる ことが想定されるケースだっため，断面は復旧せず，実 験を継続した.

また，被覆ブロックが飛散した場合を想定し，飛散後 に作用する引張力についても検討するため, 被覆ブロッ クを設置していない断面についても実験を行った．なお， 被覆ブロック設置時（case16開始前）には断面の復旧を 行った.

\section{b) 実験結果}

実験中，ひずみゲージで計測されたデータには，越流 作用前からノイズが確認されていたため，ひずみゲージ の計測值については，すべて遮断周波数を $1.0 \mathrm{~Hz}$ とる ローパスフィルターで処理を行った. マットに作用した

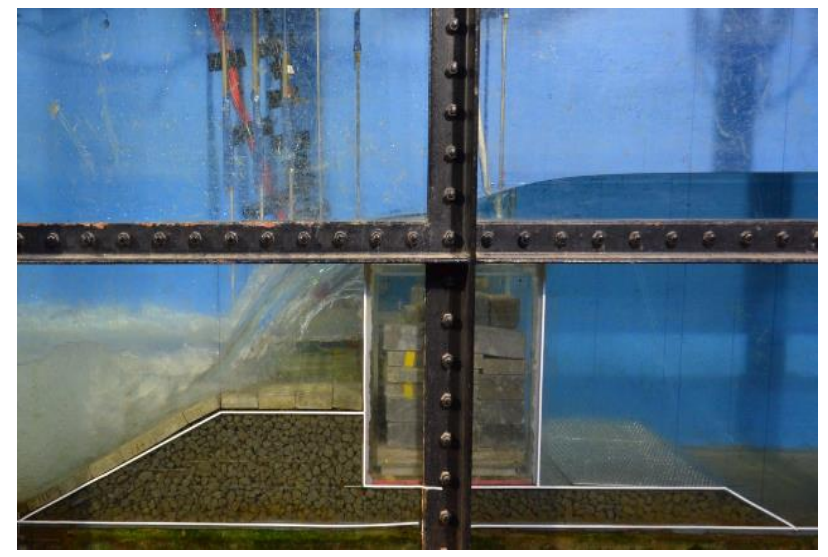

図-5 実験写真 (case 30)

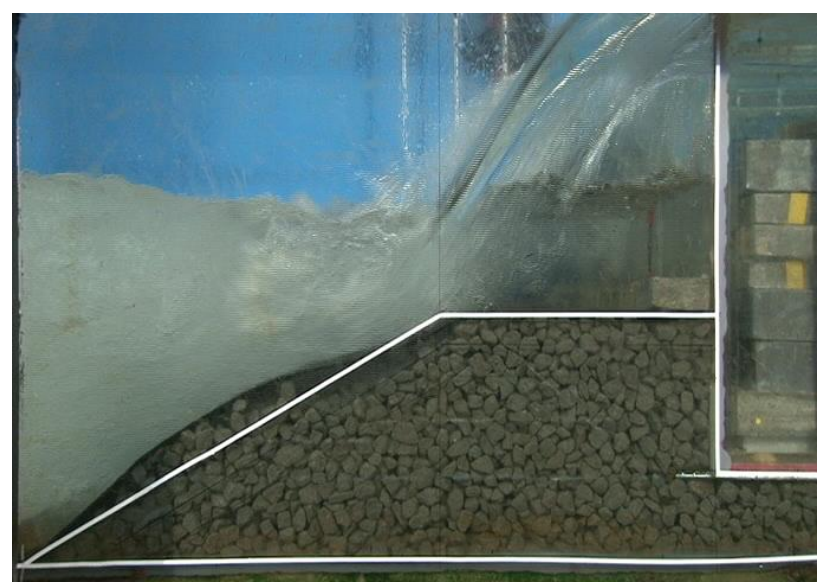

図-6 腹付け工法面の捨石の一部崩れの様子 (case15) 


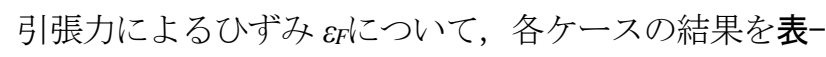
1に示寸.

今回の実験では，被覆ブロック設置時に計測されたひ ずみは，ブロックがない時のひずみに比べて小さかった マットが被覆ブロックに押さえられ，浮き上がりが生じ なかったためと考えられる. マットの強度を検討寸るう えで，安全側に設計することを考え，引張についての検 討では被覆ブロックがないケース(casel〜15)の結果を用 い解析を行った。

\section{(3) 洗掘防止マット模型の物性試験 \\ a) 引張試験}

水理模型実験で用いたものと同様のマットについて, インストロン試験機で荷重をかけ，ひずみゲージでひず みを測定する引張試験を行った。供試体の寸法は JIS A 6013に従い，供試体数は 5 体とした.

計測は，水理実験で計測された最大のひずみ変化の速 度 $1700 \mu \varepsilon / \mathrm{s}$, 実験時の水温 $7 \sim 8^{\circ} \mathrm{C}$ に合わせて最大ひずみ $1,000 \mu \varepsilon$ まで行った，その一例を図-7 に示す．それぞれ の供試体の計測結果について, 応力 $\sigma$ とひずみ $\varepsilon$ の関係 を線形近似すると，測定值と線形近似式の相互相関係数 $R$ は $R=0.98 \sim 1.0$ となり, 実験に使用したマットの応力ひずみ関係は，実験の範囲内で線形の関係であった（式 (1)）。ヤング率 $E$ にいては, 供試体 5体の平均值とし て, $E=786.5 \mathrm{MPa}$ とした.

\section{b) 付着強度試験}

付着強度試験では，5号砕石の上に，マット，コンク リートブロックを設置した. ブロックを $10 \mathrm{~mm} / \mathrm{min}$ の速 度で引き上げてマットから引きはがし, その際の荷重と 変位の関係を計測した。 なお，供試体は設置後に上から 荷重をかけ30分静置し, 水理実験での付着状態を再現し た. 実験結果の一例を図-8に示寸.

ブロックがマットからはがれ始める荷重は，サンプル によりバラつきがみられ $13.0 \sim 26.2 \mathrm{~N}$ （供試体数 5 体）， 平均值は $17.7 \mathrm{~N}(1.80 \mathrm{kgf})$ であった。これは, 載荷したと きの供試体を設置した砕石の凹凸，マット模型自身の凹 凸により付着面積に差がありばらついたためと考えられ る.ブロック，マットの孔を無視した面積で，荷重を除 した付着強度 $w$ は $w=2.77 \times 10^{-3} \mathrm{~N} / \mathrm{mm}^{2}$ であった.

\section{（4）洗掘防止マットの設計手法と安定性についての検 討}

\section{a) 引張応力についての検討}

水理模型実験と引張試験の結果から得られたひずみ $\varepsilon_{F}$ とヤング率 $E$ によマットに働いていた応力が算定され た. 各ケースごとの計測点の中で最大だった引張応力 $\sigma_{F}$ について，運動量を用いて以下のように整理を行った. 洗掘方止マットに作用するマット方向の力 $F$ による単位

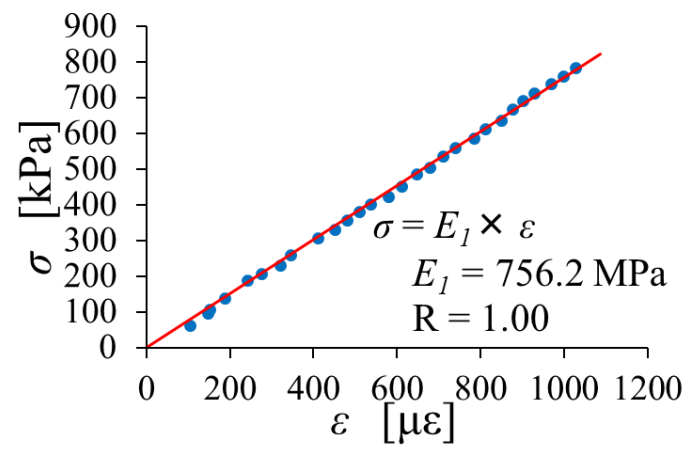

図-7 引張試験結果の一例

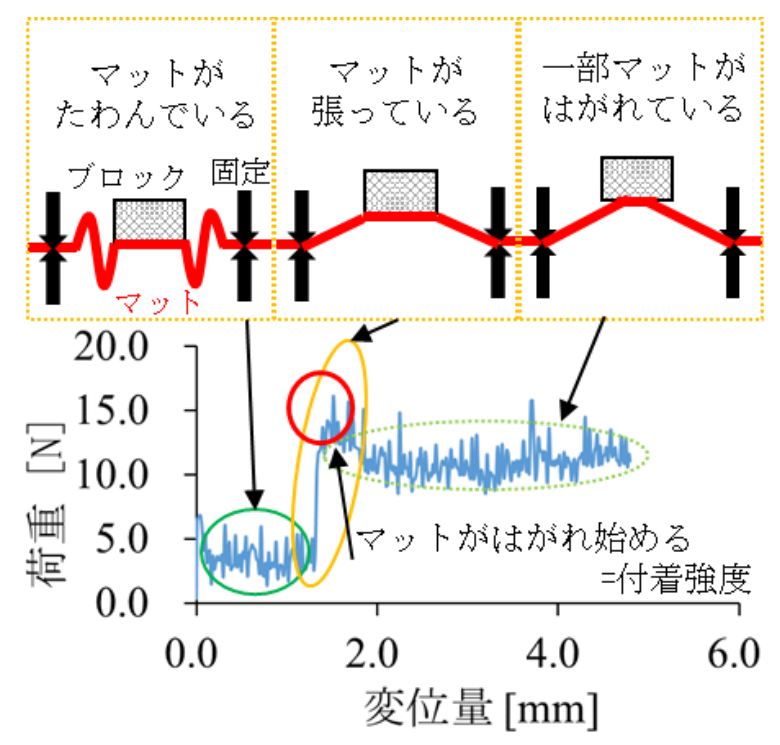

図-8 付着強度試験の結果の一例

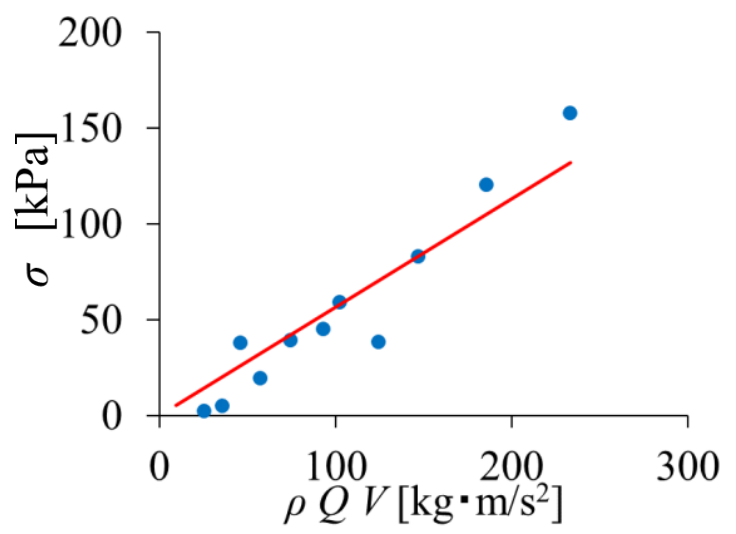

図-9 越流の時間当たりの運動量 $\rho Q V$ とマットに作用する 引張応力 $\sigma_{F}$ の関係

時間 $d t$ 当りの力積 $I$ とする. I は越流水の運動量 $m_{W} V$ に 比例するものとし, 定数 $C$ を用い, 式(2)のように仮定す る.

$$
I=F d t=C m_{W} V
$$

ここで, 越流水の質量 $m w$ は密度 $\rho$, 流量 $Q$ に時間をか けたもので式(3)のように表すことができる. 


$$
m_{W}=\rho Q d t
$$

マットに作用している引張応力 $\sigma$ は $F$ をマットの断面 積 $A$ で除したものである. 以上より, 引張応力と水理条 件の関係式は，式(4)のようにまとめられる.

$$
\sigma_{F}=F / A=C / A \times \rho Q V
$$

図-9 は越流水の時間当たりの運動量 $\rho Q V$ とマットに作 用寸る引張応力 $\sigma$ 関係である。ここで，Vは越流水が マットに衝突するときの流速であり, 堤体天端後端での 水深, 流速を用いて三井らの提案手法で求めた. $\rho Q V$ とのは比例関係にあり式(4)の係数 $C$ を適切にとることで, マットの引張応力を算定できることがわかった．また, 三井らの提案寸る算定図を用いることで，津波襲来時の 前背面水位と防波堤の形状から種々の津波越流に対寸る マットの引張応力を算定することが可能である.

\section{b) マットの試設計}

本実験の結果から得られたマットに作用寸る引張力に ついては，フルード相似則に従うものと考えられる。試 設計として，本実験で最も大きな応力が生じたケースに ついて, マット模型と同一の応力が作用するとして, 現 地スケールに換算し, 洗掘防止マットの必要強度の試計 算を行った．被覆ブロックがない場合，越流水深 $3.75 \mathrm{~m}$, 水位差 $8.5 \mathrm{~m}$ の津波の越流によって, マットには幅 $1 \mathrm{~m}$ 当 りの引張力が最大 $197.4 \mathrm{kN}$ 作用する.

ここで, 本検討ではアスファルトマットの引張に対す る強度の検討を行っているが, アスファルト合材の引張 試験は治具による固定が困難で, また, 設置後は被覆ブ ロック, 砕石などに食込み・変形し, 断面が薄くなり, アスファルト合材部分の引張強度の評価は難しい，そこ で本検討では, 芯材の強度がマット全体の引張強度と考 え設計することを提案する. 以上の検討から幅 $1 \mathrm{~m}$ 当り の引張強度が $200 \mathrm{kN}$ 以上の洗掘防止マットを用いること が必要であることがわかった.

\section{c) 付着についての検討}

例えば片岡らほは防波堤のケーソン底部に設置された アスファルトマットが，ケーソンに付着していた事例を 報告している. このことから，アスファルトを材料とし た洗掘防止マットは, 腹付工の捨石, 被覆ブロックと付 着し，その安定性を高める効果が期待される. そのため, 水理実験では，マットを設置する際に，上から荷重をか けて付着させることで，付着についても再現を試みた。

水理模型実験においての被覆ブロックについて, イス バッシュ式の, 三井ら 3)の提案手法で計算される必要質量 $m の 1 / 4$ 程度の質量でもブロックの被災は確認されなかっ た.このことから，マットの付着性がブロックの安定性 に寄与することが示唆された. そこで, 付着力を考慮し た被覆ブロックの必要質量 $m$ にについて検討を行った. マットの付着力の分布 $w$ を, イスバッシュの示した石の
回転モーメントのつり合い方程式に付着によるモーメン トNの項を加えた（式(5)）.

$$
\begin{aligned}
k \rho_{w} \frac{V^{2}}{2 g} a^{2} \xi a+\left(\rho_{s}-\rho_{w}\right) a^{3} & \sin \alpha\left(\frac{a}{2}-\zeta a\right) \\
& =\left(\rho_{s}-\rho_{w}\right) a^{3} \cos \alpha \frac{a}{2}+\frac{N}{g}
\end{aligned}
$$

ここで, $k$ : 形状係数, $\rho_{w}$ :水の密度, $\rho_{s}$ :ブロックの密度, $a$ :ブロックの直径, $\xi$ : 回転中心から抗力作用線までの距

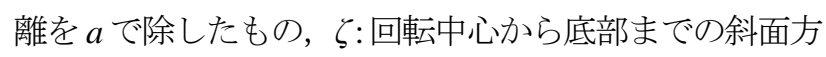
向垂直距離を $a$ で除したもの， $\alpha$ : 斜面の勾配角度である.

付着による力はブロック底面に均一に働いているもの と考えると，Nは以下のようになる.

$$
N=\int_{0}^{a} w a x d x
$$

ここで, $w$ :マットの付着力の分布荷重である.

式(5),(6)を用い，イスバッシュと同様に， $\zeta=0.5$ とし対 象物を直径 $a$ の球と仮定し必要質量 $m$ 'を計算寸る.

$m^{\prime}=\frac{\pi \rho_{S}\left(\frac{V^{2}}{2 Y^{2}}-\frac{w}{\rho_{w}}\right)^{3}}{6 g^{3}\left(S_{r}-1\right)^{3} \cos ^{3} \alpha} \quad$ where $\quad Y=\sqrt{1 / 2 \xi k}$

ここで $Y$ :イスバッシュ数, $S_{r}$ : 水に対するブロックの比 重である.

本実験ではブロックの必要質量より付着力の影響が大 きかったため, すべてのケースにおいて $m^{\prime}=0 \mathrm{~g}$ となっ た. ブロックとアスファルトマットとの付着は, ブロッ クの重量によるものと考えられるため, 被覆ブロックに ある程度の質量は必要ではあるものの, マットを用いる ことで，被覆ブロックの質量を小さくできることが示さ れた.

\section{3. まとめ}

本検討より以下のことが示された.

・腹付け工上に設置した洗掘方止マットに越流が定常的 に作用するとき，マットに作用する引張力の大きさは， その越流水の持つ運動量を用いることで精度良く算定す ることができた.

・このことから，現地においても津波襲来時の前背面水 位と防波堤の形状からマットに発生する引張応力を算定 する方法を提案した.

・試設計の結果から, 想定断面に越流水深 $3.75 \mathrm{~m}$, 水位 差 $8.5 \mathrm{~m}$ の津波の襲来が想定される場合には, 幅 $1 \mathrm{~m}$ 当り の $200 \mathrm{kN}$ 以上の引張力に耐える洗掘防止マットを用いる ことが必要であることがわかった.

・マットの付着力によって被覆ブロックの安定性が向上 することが示された. 
また，今後の課題として以下のことが挙げられる.

・マットの形状，防波堤の形状による影響についてさら なる検討が必要となる.

・本実験では，レイノルズ数 $\operatorname{Re}$ が $\operatorname{Re}=1.5 \times 10^{4}$ 程度であ ったため，縮尺による影響が懸念される．今後より大き な縮尺の実験による検討が必要となる.

・マットの付着力については，フルード相似則に従わな

いことが想定されるため, その影響を推定するにはさら なる検討が必要となる。

\section{参考文献}

1) 国土交通省港湾局: 防波堤の耐津波設計ガイドライン 2013.

2) 有川太郎, 佐藤昌治, 下迫健一郎，富田孝史，廉慶 善，丹羽竜也: 津波越流時における混成堤の被災メカ
ニズムと腹付工の効果，港湾空港技術研究所資料, No. $1269,2013$.

3) 三井順, 久保田真一, 松本朗, 半沢稔: 堤港内側マウ ンド被覆ブロックの耐津波安定性に及ぼす上部工形 状の影響, 土木学会論文集 B2（海岸工学）, Vol. 72, No. 2,pp. I_1111-I_1116, 2016.

4) 有川太郎, 岡田克寛, 下迫健一郎: 防波堤の腹付け被 覆ブロックの安定性, 土木学会論文集 B2(海岸工学), Vol. 70, No.2,pp.I_941-I_945, 2014.

5) 片岡真二, 西宏一, 矢島道夫, 三浦修: ケーソン下面 に敷設した摩擦増大のためのアスファルトマットの 耐久性について, 海岸工学講演会論文, Vol. 30, pp. 643-647, 1983.

6) Isbash, S.: Construction of Dams by Dumping Stones into Flowing Water, Sci. Res. Inst. Hydrotech. Leningrad, 1932, translated by Dovjikov, A., U.S.A.C.E., 1935.

(2017.3.15 受付)

\section{EXPERIMENTAL STUDY ON DESGIN OF SCOURING PROTECTION MAT ON WIDENING WORK}

\section{Tsukasa KITA, Toshio OHNO, Futoshi HOSHINO, Kojiro SUZUKI}

To protect breakwaters with widening works from scouring caused by tsunami overflow, it is proposed to cover widening works with scouring protection mat. However, few studies have focus on the strength design of scouring protection mat. Thus, this study conducted hydraulic model experiments and properties test to estimate tension exerted on mats against tsunami overflow.

We rearrange the experimental results from the point of view of the momentum of overflow. From the results, an experimental formula was proposed for estimating tension exerted on scouring protection mats covering widening works behind caissons of breakwaters against tsunami overflow. After that we try designing prototype-scale scouring protection mat. Additionally, it is confirmed that asphalt, which is a common material for mat, adhesion to blocks. It suggests that scouring protection mats may improve the stabilities of armoring blocks. 